\title{
Human Rights in Xinjiang 1978-2007: Internationalisation of the Uyghur Dilemma and China's Reaction
}

\author{
Roy Anthony Rogers
}

Abstract

Since 1978 when Deng Xiaoping took over the leadership of China after the demise of Mao Zedong in 1976, the country witnessed dramatic changes in the human rights situation. These included freedom in performing religious obligations such as pilgrimage, for the Muslim Uyghurs and freedom to practice their culture and language. Hence, there was an overall improvement in human rights situation in Xinjiang province. However, in the late 1990s the Chinese Communist Party reverted to harsh policies once again. They declared the policy of 'Strike Hard' which sanctioned the use of torture and arbitrary detention as well as extra-judicial killings of the Uyghurs. This article examines the factors that have influenced China's policies on the human rights condition in Xinjiang from 1978 until 2007. It also analyses the role of Uyghur diasporas in their struggle to internationalise the human rights issues in Xinjiang and China's reaction towards the international pressures.

Keywords: Human Rights, Muslim Uyghurs, Xinjiang, Chinese Policy.

\section{Introduction}

This article examines the factors that have influenced China's policies on the human rights conditions in the Xinjiang province of China between the years 1978 until 2007. More specifically it analyses pertinent issues related to the factors that have influenced the human rights in Xinjiang, the role of the international Uyghur community in their struggle to internationalise their plight and also the reaction by the Chinese government towards the pressures from the international community.

This study has demonstrated that the Uyghur's struggle to preserve their rights in maintaining their cultural and religious identity has not waned in spite of China's policies of subjugation. Unlike previous studies which only concentrated on major revolts or specific periods of Chinese administration in Xinjiang, this study attempts to analyse the internal and external factors that influenced the change in human rights conditions in Xinjiang. This study varies from previous works such as (Dillon, 2004) and (Starr, 2004). These and other works have elaborated largely on the Uyghur's sufferings under Chinese rule and their quest for independence. Xinjiang has been selected for this study because it offers a unique case study which allows for the analysis of the contributing factors which have influenced human rights policies under the administrations of Deng Xiaoping, Jiang Zemin and Hu Jintao. 


\section{Background of Xinjiang}

Xinjiang or Sinkiang is situated at the northwest of China about $4000 \mathrm{~km}$ from Beijing. Xinjiang is also the largest province in China, covering about 617,800 square miles $(1,600$, 000 square $\mathrm{km}$ ) or $1 / 6$ of the total Chinese territory. Although, Xinjiang is considered as one of the most isolated regions in the world, but its location is in one of the most strategic areas in terms of China's security and defence as it shares its borders with eight countries. These countries are Mongolia and Kazakhstan to the northwest, Russia to the north, Kyrgyzstan and Tajikistan to the west and Afghanistan, India and Pakistan (Jammu Kashmir) to the southwest. There are no other provinces in China that has as many international borders as Xinjiang (please refer to the map). Hence Xinjiang is an important province in terms of its role in China's security.
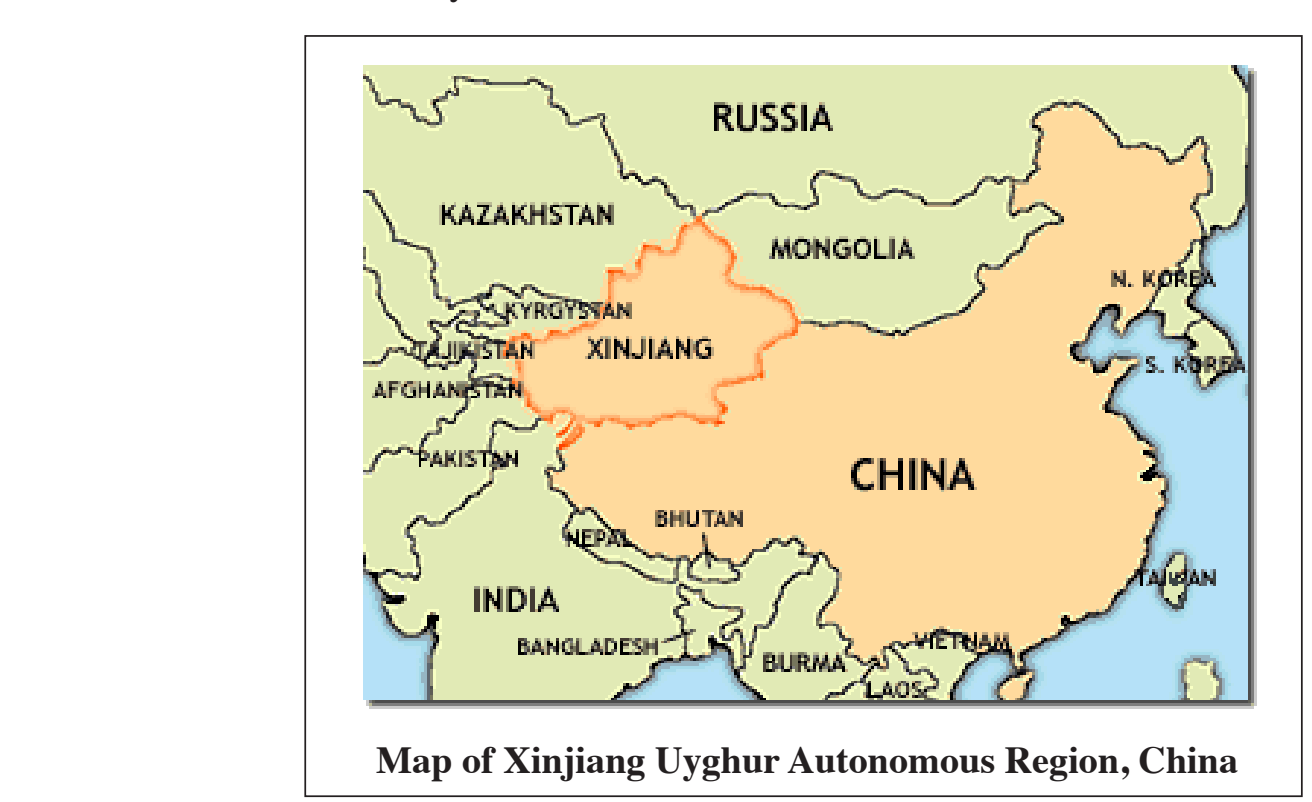

Ethnicity in Xinjiang can be divided into two main categories: the Turkic people who are natives of Xinjiang and non-Turkic people such as the Han Chinese, Russians, Manchurians and Indians. The Turkic people are made up of the Uyghur, Kazakh, Kirghiz, Uzbek and Tajik with the Uyghurs being the largest. The Uyghurs in Xinjiang are Muslims and they share a common heritage, language and religion with the other Turkics living in Central Asia. They are not confined to Xinjiang but are scattered throughout Central Asia in countries like Afghanistan, Uzbekistan, Kazakhstan, Turkmenistan and parts of Russia.

The Turkics are the same ethnically although they may be divided politically and physically. The Uyghurs who settled in the Tarim Basin, Xinjiang were introduced to the Islamic faith in the late $9^{\text {th }}$ century A.D. In fact, Islam had reached Central Asia as early the mid $7^{\text {th }}$ century A.D through Arab merchants and Islamic teachers who used the Silk Road to travel to China. SaadibnAbiWaqqas, one of the companions of Prophet Muhammad visited China 
in 650 A.D. The visit of SaadibnAbiWaqqas as an official envoy of KhalifaUthmanAffan is considered by many Islamic scholars to be the date that Islam arrived in China (Yusuf Liu, 1998). Many Central Asian tribes were converted by the Arab merchants who were on their way to China via the Silk Road.

Xinjiang is located on the ancient 'Silk Road' which was a popular route used by traders and travellers such as IbnuBatuta and Marco Polo between the East and the West. It became a Chinese territory during the Ching dynasty (1644-1911) in the mid-eighteenth century and was administered by the military. In 1884, it was declared a Chinese province and was the last area to be permanently occupied by China. The Ching dynasty named the province 'Xinjiang' which means 'New Borders' in Chinese. However many western explorers such as Sir Aurel Stain and Sven Hedin referred to the area as 'Chinese Turkestan' or East Turkestan. Despite the fall of the Ching dynasty in 1911, Xinjiang remained part of the Republic of China under the Koumintang Party (KMT).

1) The local leaders in Xinjiang launched several revolts aimed at separating Xinjiang from Chinese rule and establishing an Islamic sultanate. However, these attempts were unsuccessful as they were defeated by Chinese troops. One of the most popular Turkic revolts against Chinese control occurred in Xinjiang during the $19^{\text {th }}$ century was led by Yakub Beg that lasted for 13 years (1864 to 1877).

After the 1911 Revolution there was a transition in the Turkic separatist movement because revolts were no longer organised by Muslim religious teachers but Turkic nationalist who received their education in the Soviet Union (USSR). Even the original goals of the revolts were abandoned as the Uyghurs no longer harboured ambitions to establish a khanate. ${ }^{1}$ Instead, they wanted to form an independent republic with its own constitution.The Turkic nationalists attempted to separate the province from Chinese control by establishing the Turkish Islamic Republic of Eastern Turkistan Republic (TIRET) in 1933-34 and the East Turkestan Republic (ETR) in 1944-1945.

In 1949, the Chinese Communist Party (CCP) took control of Xinjiang from the KMT and declared that Xinjiang was to be an autonomous region in 1955. Ever since then the province has been known as the Xinjiang Uyghur Autonomous Region (XUAR).However, major decisions were still made by the CCP led by the Han Chinese and not the locals from Xinjiang. The CCP implemented aggressive assimilation policies in the 1960s especially during the Cultural Revolutionduring which the locals were subjected to serious abuses at the hand of the authorities.

In 1978, Deng Xiaoping took over the leadership of China after the demise of Mao Zedong in 1976. There was an improvement in human rights in Xinjiang. However, in the late 1990s the CCP reverted to harsh policies once again. They declared the policy of 'Strike Hard' which sanctioned the use of torture and arbitrary detentions. Thisbrought about dramatic changes in the human rights situation in China. 
According to the Census of China in 2000, the total population of Xinjiang was 18,459,511. The Uyghurs compromised 45.5 percent and the Han compromised 40.6 percent with the other minorities such as the Kazakhs, Uzbeks, Kirghiz, Tajiks, and Mongols at 13.9 percent of the total population of Xinjiang. The census also estimated that the population of Xinjiang will increase to 19.63 million by 2004 (Xinjiang Statistical Yearbook, 2005).

In recent times, there have been attempts by the Chinese government to 'revive' the 'Silk Road' by linking the province with other important cities in Central Asia such Bishkek, Almaty, Dusnanbe and Tashkent. In addition, Urumqi, the provincial capital of Xinjiang is connected to other important cities in the province such as Kashgar, Turfan, Yarland and Ili through modern highways. Other than Urumqi, Kashgar is second largest city in the province. It is also the largest oases city and is the commercial centre for western Xinjiang. It must be noted that Xinjiang is also rich with its natural resources especially oil and gas. Tarim Basin is thought to contain nearly 240 billion cubic meters of natural gas reserves and 11 billion tons of crude oil reserves (Ahmad Lufti, 2001). Besides Tarim Basin, other areas (1) such as Zhungar Basin and Turfan Depression are also oil producing regions in Xinjiang.

-

\section{Human Rights Conditions in Xinjiang Prior to the 1978 Reforms}

The human rights conditions in Xinjiang prior to 1978 can be divided into two phases. The first phase was between 1949 till 1959, which was considered as the 'accommodative' years. The second phase is known as the 'repressive' period which started in 1960 till 1978. In September 1949 the Koumintang (KMT) forces under Commander Tao Zhiyue surrendered to the People's Liberation Army ${ }^{2}$ or PLA (James A. Millward, 2005). The initial task of the CPLA and CCP was to establish a new administration in the province by gaining internal - support from the various parties including the Uyghur nationalists and the disbanded KMT - forces. At that moment the CCP adopted a tolerant policy with the aim of creating a 'united front'.

-

Gaining internal support was the major concern of the CCP during the early years of its administration in Xinjiang. The CCP wanted to appease the non Han peoples by granting autonomy to the provinces where they formed the majority.This included Xinjiang, Tibet, Ningxia, Kansu and Qinghai. Therefore in October 1955, the Xinjiang Uyghur Autonomous Region (XUAR or Xinjiang Weiwuerzizhiqu) was established (June Teufel Dreyer, 1976). The establishment of the XUAR has given the non-Hans the opportunity to govern the province in the lower levels of administration with positions such as the chairmen of counties, districts and prefectures. Hence the Uyghurs during this period enjoyed certain rights such as eligibility for special representation in an autonomous area, right to use their language and maintain their cultural and religious identity.

However, the situation began to change when the CCP consolidated its position in the province by the mid-1950s. The CCP introduced the Land Reform policy which prohibited the Islamic authorities from owning waqf lands. The lands were taken over by the government 
and later redistributed. This was part of the Marxist and Maoist development programme which promoted collectivisation of resources (Donald McMillen, 1979). In addition, the CCP also prohibited the Islamic authorities from collecting zakat and the shari'ah legal system was discontinued. Local religious leaders or ahungswere sent away to longhai or labour camps for rehabilitation. Apart from that, the Xinjiang Muslims were stripped of their rights to travel; especially to go on hajj. All Muslim holidays which had been formerly acknowledged were withdrawn.

Beginning from the 1960 s, the CCP started introducing repressive policies which replaced the accommodative policies before. Somefactors that have contributed to the change of policies were the failures of the 'Hundred Flowers Movement' ${ }^{3}$ and the Great Leap Forward 4 to achieve their objectives. These failures embarrassed Mao Zedong.Following the failure of the Great Leap Forward and criticism of the Hundred Flowers Movement in 1965, Mao Zedong wanted to reconsolidate his position in the government. He blamed the failure of the Great Leap Forward on party leaders who were liberal minded. In the following year, Mao Zedong launched the 'Great Proletarian Cultural Revolution'. It was a political campaign to purge all those whom he considered as 'liberals', such as Liu Shaoqi and Deng Xiaoping.

As a result Mao encouraged Chinese youths to establish militia groups known as the 'Red Guards'. Their aim was to monitor party members and punish those whom they considered as liberals. They also regarded religion and traditions or anyone associated with such things including academics, writers, poets, artists as feudalistic and anti-revolution who needed to be purged and 'rehabilitated'. Very often party officials who were accused by the Red Guards were demoted, sent to longhai or labour camps for rehabilitation, publicly humiliated, had their houses ransacked, physically assaulted and even killed.

In Xinjiang, the situation was not better than other provinces. Once the Red Guards from Beijing arrived in Xinjiang in 1966, they started to persecute local leaders including Wang Enmao, the First Secretary of the Xinjiang Communist Party and commander of the Xinjiang Military Region (June Teufel Dreyer, 1976). He eventually was removed from all positions in Xinjiang and transferred to Beijing. During the Cultural Revolution, the Red Guards were opposed to the policies of accommodation and local autonomy, therefore many Uyghurs were deprived of their jobs in the government. In 1962, there were 111,500 Uyghurs working for the provincial government holding various posts such clerks, policemen, district and county chairmen. However, in 1975, there only 80,000 non-Hans left working in the government (James A. Millward, 2005). In addition, the CCP had always been suspicious of Islam and the Uyghur traditions which they considered as feudalistic and anti-revolution. Hence they were convinced that the influence of Islam and Uyghur traditions should be wiped out through the implementation of harsh policies.

Another factor was the Sino-Soviet rivalry which influenced Beijing to adopt harsh policies during the 1960s. The CCP wanted to eliminate Soviet influence in the province and the CCP feared the Soviet may interfere in the internal politics of Xinjiang as part of its plans 
to attack China. The CCP had increased the Chinese military presence in the province. This had resulted to the militarisation of Xinjiang. The aim was to defend the province against any possible Soviet invasion at all cost. Often Uyghur leaders were accused by the Red Guards as spies of the Soviet and sent to labour camps for rehabilitation, publicly humiliated, physically assaulted and killed.The political turmoil between China and the Soviet Union encouraged the CCP to adopt repressive policies which resulted in a decline of human rights conditions.

The conditions turned for the worse during the reign of the 'Gang of Four'. Mao's wife Jiang Qing, who was one of the members of the Gang of Four, had openly expressed her hatred of Xinjiang and the Uyghurs. She was quoted as saying "what is special about your tiny Xinjiang? I despise you." (Ann Kent, 1993: 103) She even called the minority nationalities including the Uyghurs as "foreign invaders and aliens." (Ann Kent, 1993: 103) During the Cultural Revolution and Gang of Four, apart from being deprived of their political and civil rights, the Uyghurs also encountered religious and cultural persecution. During the Cultural

1) Revolution religious tolerance as prescribed by the PRC Constitution of 1949 was as good as dead.

-

\section{Factors Influencing Human Rights Conditions Xinjiang since 1978 Reforms}

There were several factors that influenced the human rights condition in Xinjiang since 1978. They include the Chinese Communist Party's (CCP) perspective on human rights, the economic development in the region and the security conditionsof the province, the global war on terror. It is important to note that China has made use of these factors to preserve 1 its interest in Xinjiang. This includes territorial integrity and security of the province, protection of the Chinese Han and continuouseconomic development. Although the Chinese government has granted certain rights to the minorities since the early 1980 s but it would do whatever it takes to protect its interest which includes intolerance to any secessionist attempts in Xinjiang.

\section{Chinese Communist Party (CCP)'s Perspective on Human Rights}

China adopted the human rights norms not because it was convinced by them nor felt morally obligated to adopt them instead it was motivated by its national interest. It must be noted that China prefers to define human rights based on its own understanding as the Chinese Communist Party (CCP)'s perspective on human rights plays an important role in shaping the human rights condition in Xinjiang. The core elements of the CCP's human rights policy can be divided into two points.

Firstly, the CCP stresses that economic development of the state should be given top priority at the expense of human rights. According to the $\mathrm{CCP}$ it is imperative that a suitable national conditionfor economic growth exists over observing and promoting any civil or political rights (Xinhua, 1994). Secondly, the CCP is convinced that human rights should be based on its own national characteristics which include its level of development, political systems, 
culture and history. Hence it must be made clear that the human rights condition in Xinjiang is influenced by the CCP's understanding of human rights (Zhou Wei, 1995).

The CCP started to give emphases on human rights or renquanduring Deng Xiaoping's administration when the People's Republic of China demonstrated an interest in overall human rights by ratifying several international human rights treaties (Michael Dillion, 2009). There wasan improvement in the human rights condition in China when compared to Mao Zedong's repressive policies especially during the Cultural Revolution. China has always argued that it is not against human rights norms as long as these norms serve national interest and integrity. For example, since the early 1980s China has granted more freedom to the minorities, such as granting them rights to practice their religion and culture openly. - In addition, China became a member of the Human Rights Commission in 1982. China has also ratified several human rights conventions, such as the International Convention on Elimination of all Forms of Racial Discrimination, the Convention on the Prevention and Punishment of the Crime of Genocide (Kent, 1993).

In the 1980s, Deng Xiaoping shaped the CCP's ideas on human rights based on Marxism and Chinese nationalism. In fact, he openly declared that the Chinese understanding of human rights was different from those advocated in the West. Deng pointed out that it wasn't fair to judge China's human rights record based on the 'western' values which he considered as incompatible to Chinese values. According to Deng, "our concept of human rights is in essence, different from that of the Western world, because we see the question from a different point of view" (Kent, 1993: 75).

Deng argued that maintaining national sovereignty was more important than human rights. According to Deng, "actually, national sovereignty is far more important than human rights, but the Group of Seven often infringe upon the sovereignty of poor, weak countries of the Third World. Their talk about human rights, freedom and democracy is designed only to safeguard the interest of the strong rich countries, and which pursue hegemony and practise power politics" (Kent, 1993: 75).

In fact, China has been using propaganda to convince its fellow citizens that criticism from the international community, such as Amnesty International (AI) and the United States regarding its human rights records in Xinjiang and Tibet can be considered as interfering in their national sovereignty.

Instead, China prioritises the right to peace and development as being far more important than human rights. Therefore, in the case of Xinjiang the stability of the province is crucial in ensuring its economic development to the extent of sacrificing human rights. Since the Deng Xiaoping's administration China has always argued that economic development supersedes human rights norms. Hence, Deng advocated the idea that 'development is the absolute principle' in which the state's primary duty is to develop its economy. This is because it is only by developing its economy can a necessary material foundation be laid for a comprehensive guarantee of human rights (Zhu Majie, 2002). 
Deng Xiaoping's ideas on human rights managed to influence the CCP and its leaders even after he retired from the political scene in 1992. Following his death in 1997, China still regarded him as the chief architect of China's economic reforms and China's socialist modernization. Hence subsequent leaders continued Deng's approach to the issues related to human rights although they have made some minor modifications. Deng Xiaoping's ideas have influenced the CCP leaders in Xinjiang such as Wang Enmao and Wang Lequan that the stability and prosperity of the province was their primary concern. Whereas, ensuring human rights norms being observed, was secondary. In fact if the position of the CCP was threatened by separatists they were willing to forsake human rights norms.

\section{Economic Development in Xinjiang since 1978}

The demise of Mao Zedong in 1976marked the end of an era of ideological narrowness in China and ushered in a period of reorientation and restructuring based on economic development. New pragmatic leaders such as Deng Xiaoping and $\mathrm{Hu}$ Yaobang knew that for China to progress economically it required the support of all the minorities including the Hui Muslims and the Uyghurs. In Xinjiang, the CCP adopted liberal policies for minority nationalities with the aim of resolving the problem of ethnicity and creating a common identity through economic development. For example the 1978 Constitution emphasised the importance of national minorities. It guaranteed freedom for the minorities to maintain their language, customs and representation in the government (June Teufel Dreyer, 1976).

I

It is noteworthy to mention that the primary aim of the liberalisation of policies was to gain the support of the Uyghurs in order to develop China's agriculture, industry, science $C$ and technology and defence. The ultimate aim was to serve China's national interest by providing some basic freedoms to the Uyghurs so as to seek their cooperation in developing - Xinjiang's economy. The CCP was aware that the Han Chinese cannot achieve this without Uyghur support.

-

During the Fifth National Congress of the People's Republic of China in 1982, the Constitution of the People's Republic of China adopted several provisions aimed at ensuring the basic rights of the minority nationalities (Constitution of the People's Republic of China, 1982). Among them was the declaration that all nationalities in the PRC were equal and any discrimination against any nationality was prohibited. In addition, the constitution of 1982 also guaranteed that the administration of the autonomous regions, prefectures and counties were headed by a citizen of the minority nationality. Beijing has also reaffirmed its financial commitment in assisting the minorities to accelerate their economic and cultural development (Constitution of the People's Republic of China, 1982).

Subsequently in the mid-1980s, economic development in minority areas such as Xinjiang became a major concern of the CCP. Its aim was to integrate the economy of its western region with central China. The $\mathrm{CCP}$ had initiated several affirmative actions for the Uyghurs. These included financial assistances, recruitment and promotion of Uyghurs in 
government departments, admission of Uyghur youths into public schools and universities and improvement in the public infrastructures in areas populated by Uyghurs.

The Constitution of 1982 also ensured some religious freedoms on condition that it did not disrupt the stability of the state. Religious sites in Xinjiang were restored and the use of Uyghur language in local schools was allowed. However, the schools were still government controlled. In 1980, the CCP of Xinjiang permitted the use of the Arabic script for the Turkic language (Cuiyi Wei, 1993) and in the same year, the Xinjiang Islamic Association (XIA) was given permission to reintroduce the Arabic script for the Uyghur and Kazakh languages. In 1984, 15,000 imams were trained and 150,000 copies of the Quran were published in Xinjiang (Cuiyi Wei, 1993). As a result more than 23,000 mosques were built and Uyghurs were allowed to perform their Hajpilgrimage. The numbers of Haj pilgrims from China have increased from 260 in 1985 to 2,000 in 1995. Gou Chengzhen, the Deputy Director of the Department of Muslim Affairs claimed in 2006 there were 7,000 Chinese Muslim performing their Haj (Mahesh Ranjan Debata, 2007).

The reform and opening-up of policies advocated by Deng Xiaoping, brought mixed reactions. On the one hand, the CCP placed great importance on the construction of basic communications, power generation and telecommunication facilities (Beijing Review, 1994). Hence, from the 1990s onwards, Xinjiang enjoyed further economic development especially after the disintegration of the USSR. With the demise of the Soviet threat, the Chinese government was able to develop the northwest region and attract more foreign investments. On the other hand, economic development has further contributed to the influx of Chinese Hans into the province and alienated the Uyghurs from mainstream development.

The mass migration of Hans to Xinjiang was justified on the grounds of providing manpower for economic development. This impacted the human rights conditions in Xinjiang because as the number of Han Chinese increased the CCP was obligated to ensure that their socioeconomic condition was given priority at the expense of the locals. Steps were taken to provide accommodation and employment prospects which were once held by the Uyghurs. Therefore, this led to the competition over socio-economic rights and privileges between the Han Chinese migrants and the locals.

\section{Political Violence in Xinjiang and the Uyghurs Separatism}

Security was another factor which influenced the human rights conditions of Xinjiang. Since the mid 1990s the outbreak of political violence had been very serious and human rights norms wereconstantly ignored. The primary concern of the Chinese Communist Party (CCP)was to ensure China's control and stability of the province.

It is noteworthy to mention that China was even willing to adopt policies that violate human rights in order to subdue any secessionist attempts by the Uyghurs especially when the safety of the migrants Hans living in Xinjiang was threatened. The PRC administration in Xinjianghas been encountering opposition from the Uyghurs from the beginning. They 
considered the CCP to be a foreign entity who had taken over their homeland. As a result, there were several waves of rebellions against the CCP. It is important to note that every ten years the province will experience a major rebellion. The objectives of these rebellions were to separate the province from China and establish an independent republic. It should also be noted the animosities between the Hans and the Uyghurs were deeply rooted in the history of uneven relations between the Hans and the Uyghurs. The contemporary situation in Xinjiang has also increased to the animosity between them. This has caused the Chinese authorities to be sceptical in granting more freedom and rights to the Uyghurs. They fear such actions will future enhance their demands for independence.

In addition, the harsh policies during the Cultural Revolution have had a negative impact on both the Han Chinese and Uyghur communities. For the Han Chinese, the Cultural Revolution has convinced them that the way to administer Xinjiang 'peacefully' is through harsh policies that ignores any human rights norms. However, for the Uyghurs the harsh treatment and excesses of the Cultural Revolution have increased their hatred toward the CHan Chinese.

-

This has caused political violence and separatist activities in the province to increase in the 1980s and 1990sdespite some conciliatory measures which were undertaken by the CCP during the Deng Xiaoping administration. The re-establishment and relaxation on the practice of Islam as well as Uyghurlocal traditions and culture have led to the revival of Islam and the Uyghur identity.The resurgence of Uyghur nationalism was also due to the opening up of borders by the Deng Xiaoping's administration as part its efforts to encourage economic development with the border regions.

()

The impact of opening up of borders has increased the contacts between the Uyghurs and other Muslims living in Pakistan, Central Asia and the Middle East, which have exposed the Uyghurs to radical ideals (Rogers, 2007). During the 1980s the Chinese government had in - fact recruited some Uyghurs to flight with the Mujahideens against the Soviet occupation in Afghanistan..$^{5}$ Besides the Uyghurs other Turkic people from Xinjiang including the Kyrgyz, Kazakh, Uzbek were recruited by the Chinese military intelligence. They were selected because of their cultural and religious empathy with the Afghans. According to Rashid the Pakistani officials have confirmed that hundreds of Uyghurs were trained in Pakistan to fight against the Soviets in Afghanistan (Ahmed Rashid, 2002). Upon the withdrawal of the Soviet troops from Afghanistan many of the Turkic fighters returned to Xinjiang (Clarke, 2009). However they continued their 'battle' against the Communist ideology in Xinjiang. Hence, the Uyghurs resistances have turned more violent by using methods such as bombings, burning down government buildings and the, killing of government officials. Although the CCP, had undertaken some conciliatory measures, however, they were unable to appease the Uyghurs. The Uyghurs demanded for better employment prospects and greater autonomy. Moreover they wanted the CCP to stop the policy of mass migration of Hans into Xinjiang. 
In the 1980s, Xinjiang encountered a series of armed resistances such as the riots that occurred in Aksu which is located between Urumqi and Kashghar (Mahesh Ranjan Debata, 141). It occurred in April 1980 and the CCP had to bring in the People's Liberation Army (PLA) to subdue the riots.The riot turned violent when the rioters started to attack the local Hans who were living in Kashghar. The rioters shouted anti-Chinese slogans such as 'Down with the Heidaye government' and 'Long Live the Republic of Uyghuristan'(Mahesh Ranjan Debata, 141). Finally the CCP had to mobilise the PLA to subdue the rioters. According to the Chinese sources the outbreak of violence resulted in two deaths, 200 injured. By the end of 1981, at least 30,000 Hansfled Xinjiang for Shanghai due to fears of being attacked by anti-Han demonstrators (Dillion, 2004). Such incidents have provoked the Chinese authorities to implement more stringent laws and regulations such as the 'strike hard policy'. There were several other riots in the 1980s involving theUyghurs in Xinjiang demanding for better treatment and independence. These demonstrations have contributed to the hostility between the Han Chinese authorities and the Uyghurs. For the Hans, the Uyghurs were challenging their presence openly in the province hence they had to be subjugated regardless of any human rights norms.

- Hence, in the late 1980 s these liberal policies were halted due to the fear that ethno-religious sentiments might provoke unrest in Xinjiang. Since the 1980s and 1990s the Uyghurs resistances have turned more violent by using methods such as bombings, burning down government buildings and the, killing of government officials. Another important feature of the resistance was the rise of religious militants and the use of small arms like machine guns, hand grenades and dynamites in their attacks. Therefore this convinced the CCP to impose more stringent laws regardless of human rights norms.

In addition, the disintegration of the Soviet Union and independence of the Central Asian republics have led to an increase in separatist activities by Uyghurs wanting to establish 'Uyghuristan' in Xinjiang. Many of them were disappointed with the CCP as they had an impression that the disintegration of the USSR will led to independence or at least increased autonomy in their own province. Moreover, many Uyghurs were dissatisfied with the limited liberalisation policies adopted by the CCP since the 1980s. Therefore this has resulted in an increase in public criticism by the Uyghurs throughout the early and mid-1990s that ranged from university protests to ethnic and civil unrest

The struggle between the Chinese authorities and Uyghur separatists continued into the 2000s. In the demonstration on 5 July 2009at least 1000 Uyghurs protested and attacked the Han Chinese. Police attempted to quell the rioters with tear gas, water hoses, armoured vehicles, and roadblocks; as a result the government imposed a curfew in most urban areas. Two days later, on 7 July, the Hans retaliated against the Uyghurs. According to the authorities 197 people were killed and 1,721 were injured.In addition to the loss of lives, many vehicles and buildings were destroyed (Leonard, 2009).

The Chinese were caught in a Catch-22 situation. ${ }^{6}$ This was because if they were to grant further freedoms to the Uyghurs, they would be more content with the government but 
would also increased their ethnic and religious identity which leads to Uyghur separatism and apathy toward the Han Chinese. The crucial issue for the CCP is not whether the human rights conditions in Xinjiang has improved but ensuring the safety and security of the province and the Han Chinese living in Xinjiang takes precedence.

\section{The 'September 11 Attack' and Global War on Terror}

Another major factor that has influenced the human rights conditions in Xinjiang is the global war on terror. In the aftermath of the September 11 attacks on the United States, the Chinese government made use of the tragic attacks to blame the Uyghurs solidarity groups as part of Al Qaeda.

-

It is important to note that prior to the September 11 attacks, the Chinese government denied the involvement of external terrorist groups in the separatist movements in Xinjiang. Chinese propaganda has always painted the Xinjiang separatists as an internal problem and did not require any foreign interference. However, since the September 11 attacks, Beijing has initiated its own war on terrorism. They accused the Uyghurs groups of having connections with Osama bin Laden's global terrorist network to flight for an independent East Turkestan. They even blamed the actions of the separatist movements in Xinjiang during the 1990s as 'terrorist activities'.

This has resulted in an increase in the crackdown of armed separatist group, non-aggressive Uyghur solidarity groups and all Muslims living in Xinjiang whom they suspect as terrorists. On 21 January 2002, the Chinese government declared that "terrorist forces" in Eastern Turkestan would not escape punishment" (Xinhua, 2002). On 1 February 2002 the Xinhua News agency announced that the Chinese authorities had identified 50 terrorist organisations in Xinjiang whereas previously it has never admitted that the province was facing any threat from terrorist groups (Xinhua, 2002). Since January 2002 the Chinese had even organised

- exhibitions in major cities of Xinjiang to demonstrate to its people and foreigners that the

- Uyghur groups are linked to terrorist networks (Special Report about the Human Rights Situation in Eastern Turkestan, 2002).

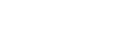

It is noteworthy to mention that the Chinese government has never requested aid from the international community in solving the separatist problem in Xinjiang. However, on 24 January 2002, the Chinese government publicly appealed to the international community for assistance in fighting the so-called terrorist forces in Eastern Turkestan (Xinhua, 2002). For example, Wang Yi, the Chinese Deputy Minister of Foreign Affairs during the Munich Conference on Global Security on 2 February 2002, said "the world community should back up the efforts of the Chinese government in fighting terrorists in Eastern Turkestan" (Xinhua, 2002).

China made use of the incident to increase penalties on those found guilty of being in any way 'connected to terrorist organisations'. AI reported that in March 2002 the repression in Xinjiang has intensified. According to the AI report the Chinese authorities had imposed 
new restrictions in Xinjiang, especially on the Islamic religion, by closing down 'illegal' mosques and subjecting Uyghur Muslim religious teachers to close scrutiny and "political education' (China's War on Terrorism-Brutal Repression of Ethnic Unrest in Xinjiang, 2002). Repressive policies were also targeted on all opposition activities in the province including peaceful expression of views via pamphlets, books, magazines, speeches, songs, poems and the internet.

The Uyghurs were discouraged from demonstrating their culture and traditions publicly. This includes observing folk customs during weddings and funerals without gaining approval from the Chinese authorities. According to AbulahatAbdurixit, the Chairman of the Xinjiang Uyghur Autonomous Region (XUAR), all forms of separatism including art must be curtailed. AbulahatAbdurixit said, "all who openly advocate separatism using the name of art' would be purged" (China's War on Terrorism-Brutal Repression of Ethnic Unrest in Xinjiang, 2002).

In addition, the $\mathrm{AI}$ and the Uyghur Diaspora groups have also reported that from September 2001 to the end of 2001, at least 3,000 people were arrested during a political crackdown in Xinjiang (Uyghur American Association [UAA] urges People's Republic of China [PRC] to Adhere to International Legal Norms, n.d.). The HRW also provided similar information in its reports published in 2002 and 2008 that since the September 11 attacks, the Chinese authorities intensified its restrictions in the province including artists, writers, performers, lecturers and historians. Brad Adams, Asia director for the HRW said, "the worldwide campaign against terrorism has given Beijing the perfect excuse to crack down harder than ever in Xinjiang" (War on Terror or Misguided Muscle?, n.d.).

In August 2002, China received a boost when the United States sided with China by declaring the East Turkestan Islamic Movement (ETIM) as a terrorist organisation. This was later followed by the United Nations (UN). Hence, with the US and UN supporting China's claim, the Chinese were able to justify their repressive policies in the name of security. As a result, according to the AI report, there were more political arrests conducted arbitrarily. It is noteworthy to mention that human rights advocacy groups such as the AI and HRW claimed that the US action was politically motivated in order to win the Chinese support for its global war against terrorism especially in the invasion of Afghanistan. The AI and Uyghur Diasporas groups have launched campaigns on like minded states like the US for condoning the violation of human rights by China in the name of war against terror. They claimed that the Chinese has deliberately over estimated the ability of the EITM in order to get away with their harsh policies in Xinjiang because of the international fear of terrorism.

It must be noted that China's concern over terrorism is justified but the problem has been exaggerated for political reasons. It is undeniable that, since the 1990s, Xinjiang encountered several serious disturbances and political violence. Some of these disturbances were inspired by religious extremists such as the Taliban from Afghanistan. In fact some Uyghurs were involved in the Afghan War and Chechnya insurgency. The US has even detained some 
Uyghurs in its base at Guantanamo Bay, Cuba. However, these are just a small number and they do not represent the entire Uyghur community. In fact, many Uyghur nationalists were Muslims who adopted secularism in their struggle for independence. Hence it isn't fair to brand all Uyghur solidarity groups and nationalists as Islamic militants.

\section{Internationalisation of the Human Rights Issues by the Uyghur Diasporas}

The Chinese restriction on public protest, state-controlled media and harsh laws such the New Criminal Law have suppressed most Uyghur organisations and individuals in Xinjiang so as not to reveal their conditions and voice their frustration publicly within the province. Hence, they have to rely and cooperate with their fellow Uyghurs in the diaspora to voice their plight and gain international support. Their aim was to provide an alternative view to the Chinese propaganda regarding the situation in Xinjiang. They wanted to garner support from the international community in order to pressure China to improve its human rights policy in Xinjiang.

In August 1999, Rebiya Kadir, a renowned Uyghur businesswoman and social activist was arrested. RebiyaKadir's arrest received international attention and the AI studied the case and launched a campaign for her release. Ever since the arrest of RebiyaKadir, the AI has started to publish special reports on the human rights conditions in Xinjiang (Amnesty International Library China: Women's Rights Action 2000 Arbitrary Detention of Rebiya Kadeer a Women's Human Rights Defender and Prisoner of Conscience, 2000) Rebiya Kadir was finally released on March 2005 and later granted permission to go to the US. Similarly in 1999, Anwar Yusuf, another Uyghur activist who was then the president of the $C$ Eastern Turkistan National Freedom Center based in Washington D.C met with President - Bill Clinton to voice the frustrations of the Uyghur people and sought the support of the U.S in regards to the plight of the Uyghurs (Gladney, 2004).

- According to Shichor, there are approximately 500,000 Uyghurs living abroad. This is equivalent to representing between five to six percent of the total Uyghur population in the world (Yitzhak Shichor, 2002). However, some Uyghur groups have claimed that the number maybe as high as 10 million (Gladney, 2004). Large numbers of the Uyghur diasporas have expressed their concerns regarding the human rights situation in Xinjiang. There are at least 25 international organisations and websites dedicated to monitor conditions in Xinjiang and pressure China. Some of these organisations have called for the independence of 'Eastern Turkistan' (Xinjiang). Most of them are based in Istanbul (Turkey), Washington D.C. and New York (United States), Amsterdam (Holland), Munich (Germany) and Melbourne (Australia) (Gladney, 2004).

There are several websites dedicated to the internationalisation of the Uyghur cause. One of them is the Turkestan Newsletter which can be viewed at http://www.turkiye.net/ sota/sota.html; it is managed by the Foundation for Research into Turkestan, Azerbaijan, Crimea, Caucasus and Siberia or SOTA ${ }^{7}$ which is based in Holland. Other websites such 
as the virtual library of Eastern Turkestan http://www.ccs.uky.edu/-rahim/et.html and the Uyghur Information Agency's website http://www.uyghurinfo.com provides information regarding the actions of the Chinese police against the Uyghurs in Xinjiang. The virtual library of Eastern Turkestan is based at the Australian National University and managed by AbdulrakhimAtibayev a Uyghur diaspora (Gladney, 2004).

In addition, there are also other websites which highlights the human rights condition in Xinjiang. These sites are managed by Uyghur diasporas with the support of the Uyghurs living in Xinjiang. Their aim is to provide an alternative source of information to voice the plight of the Uyghurs. These groups seek to gain international attention and support to pressure the Chinese government to reform its human rights policy in Xinjiang. They include the Uyghur American Association http://www.uyghuramerican.org based in WashingtonD.C., International Taklimakan Human Rights Association (http://www.taklamakan.org), the East Turkistan National Congress (http://www.eastturkistan.com) based in Munich and the Biz Uyghur (http://www.bizuyghur.com). They also maintain a bulletin board for on-line discussions on the situation in Xinjiang (Gladney, 2004).

\section{China's Reaction towards the International Pressures}

China emphasised its position that human rights are a valid subject of international discussion as long as there is no trespass into its domestic affairs. One of the counterattacking strategies is that the like-minded states such as the United States and Germany had committed human rights violations more deplorable than what happened in Xinjiang such as slavery and the Holocaust. China also alleged that there were double standards by states which criticised its human rights policies in Xinjiang. China claimed that other countries whose violations were much worse were ignored by the US. According to China the double standard was part of the attempts by the capitalist states to prevent China adopting their own choice of political system (Nathan, 1994).

Besides that the Chinese propaganda has also raised the issue of sovereignty and national integrity. It claims that foreigners who criticised its human rights condition were interfering into China's domestic affairs. Locals who were supportive of the international criticism were considered as traitors and could be charged for conspiring with the enemies of the state. According to China, many so called 'violations' of human rights in Xinjiang were not violations at all because foreign observers such as the AI and IHRC did not understand the 'actual' situation in the province.

In addition, China argued that cultural standards between China and the rest of the world were different; therefore foreigners cannot impose their understanding of human rights upon China. It considered any foreign interference to impose their ideas of human rights as 'cultural imperialism'. Moreover, China also argued that the human rights conditions in the like-minded states are not perfect, hence they have no moral authority to judge or criticise China. Former Vice-Premier Zhu Rongji said "I cannot see those countries who are promoting human rights have better record than ours" (Nathan, 1994: 641). 
Another strategy was to discredit the Uyghur solidarity groups by claiming that they advocate terror and violence in order to achieve their aims. China has raised the issue of national security and accused most of the Uyghurs solidarity groups of being terrorists. The Chinese government alleged that the attacks during the Olympics 2008 Games were planned by the Uyghur separatists. According to Amy Reger ${ }^{8}$ the CCP officials in Xinjiang such as Wang Lequan and NurBekri have attempted to link human rights organisations with terrorism and alleged terrorists groups in order to discredit their human rights efforts. Amy added that the Chinese government have also resorted to character assassination with respect to Uyghur activist RebiyaKadeer in a attempt to blame her as well as to discredit her human rights advocacy. In September 2009 NurBekri alleged the WUC as an organisation that promotes violence although the WUC has publicly denied its involvement with the July 2009 Riots (Human Rights in Xinjiang: Recent Development, 2009). Therefore, China justifies its harsh policies such as the 'Strike Hard Policy' as necessary so as to defend its territorial integrity against the Uyghur separatist movements.

Although China adopted the defensive approach in handling international criticism, it has also published several White Papers on human rights and the conditions in Xinjiang. These were significant as a sign of China's willingness to respond to international concerns and they were part of the Chinese propaganda to provide some explanation to the international community. Premier Li Peng stated "We believe that the human rights and fundamental freedom of all mankind should be respected everywhere. China agrees that questions concerning human rights should be the subject of normal international discussion" (Andrew J. Nathan, 1994: 642). The Radio Free Asia (RFA) has alleged that in 2002 the Chinese government in Xinjiang has invested nearly $\$ 40$ million in a project to jam international Pbroadcasts (China's Changing Strategic Concerns: The Impact on Human Rights in Xinjiang, 2005).

-

China released its political prisoners if not imposed more moderate sentences on some - Ef its political detainees, primarily those who were internationally well-knows such as RabiyaKadeer. At the international and regional level China has dissuaded Central Asian states such as Uzbekistan, Kazakhstan who were initially sympathetic to the Uyghurs. China through the Shanghai Cooperation Organisation (SCO) has pressured member states not to offer any assistance to the Uyghur dissidents and political activists. For example, China was able to influence the Turkish government to reject the visa application of RebiyaKadeer to attend the NED Conference which was held in Istanbul in 2006 (Human Rights in Xinjiang: Recent Development, 2009). China also responded to international pressure by granting passports to some dissidents. Most of them were of Han origin such as Wang Ruowang and Li Honglin (Nathan, 1994). They were Han political activists who demanded for democratisation however in the case of Xinjiang, the Uyghurs were not as lucky. Many Uyghurs leaders who criticised the Chinese policies were detained and send to longhai (ideological reform centres). They were subjected to harsh treatments and their requests for remission of sentence were never granted. 
Central Asian republics have also cooperated with China to deport and extradite Uyghurs back to China. For example in 2006, the Uzbek government has deported a Canadian Uyghur to China. Subsequently in the following year he was sentenced to life in prison. Despite the Canadian Prime Minister Stephen Harper's intervention requesting the Chinese government to grant the detainee counsellor access, request was not granted (Human Rights in Xinjiang: Recent Development, 2009). Another, example is Pakistan has rounded up Uyghurs who were sympathetic to the plight of their fellow Uyghurs in Xinjiang. The Pakistani government has repatriated them back to China. China has also pressured Kazakhstan and Kyrgyzstan to control the Xinjiang separatist movements within their borders. For example in 1994, Kazakhstan announced that it will not tolerate any separatist activities concerning Xinjiang. Similarly in 1995 the Kazakh government announced that it will not condone any separatist activities related to Xinjiang and in December the Kazakh police disrupted the World Uyghur Conference held in Almaty (Kostreewa, 1996). In addition, Saudi Arabia has denied the Uyghurs visas for to perform their Hajj unless they have pre-approval or clearance from the Chinese. For example in 2008, about 1000 Uyghurs in Pakistan demonstrated in front of the Saudi Embassy because their application for visas to visit the country for pilgrimage - purpose were turned down.

Besides that China has also pressured states from providing humanitarian assistance to the Guantanamo Uyghur detainees. It must benoted that the economic and diplomatic threat of straining relations with China by assisting the Uyghurs had been enough to discourage states from supporting the Uyghurs regarding the human rights conditions in Xinjiang. Moreover Western governments do not share common and united stand over human rights in China. Their relations with China are driven by economic benefits and security issues rather than on human rights issues. China has also made itself very clear that any 'foreign interference' on its domestic politics would jeopardise its relations with China. For example, during the European Union's Human Rights Dialogue with China on 8 February 1999, China's Vice Minister of Foreign Affairs, Wang Guangya mentioned that "any country which wishes to resume the Geneva scenario would certainly do damage not only to the bilateral relations but also to the possibility of continuing the human rights dialogue" (Amnesty International, 1999: 2-3).

\section{Conclusion}

Xinjiang is critical to China in geo-political and geo-strategic terms because it borders with Afghanistan, Kazakhstan, Kyrgyzstan, India, Pakistan, Russia and Mongolia. Hence it presents a greater challenge for China compared to Tibet.This article has sought to explain the human rights conditions in Xinjiang from 1978 until 2007. This study has investigated the factors that have influenced China's policies on the human rights conditions in Xinjiang within this period of time.Besides this study also focused on this particular timeframe because the human rights conditions in Xinjiang had experienced a rather 'turbulent' journey since reforms began in 1978 . 
One of the major factors is the Chinese Communist Party's (CCP) perspective on human rights. The CCP believes that theeconomic development of the state should be given top priorityat the expense of human rights. According to the $\mathrm{CCP}$, it is more crucial to ensure that a suitable national condition or guoqing for economic growth exists than to observe any civil or political rights (Xinhua, 1994). Moreover, the CCP is also convinced that human rights should be based on its own national characteristics which include its level of development, political systems, cultures and history. Hence, it must be made clear that the CCP's understanding of human rights have a tremendous influence on the human rights conditions in Xinjiang (Zhou Wei, 1995).

The Chinese government has acknowledged international criticism against its human rights policies although it refuses to admit these allegations. The primary concern of China is its image, therefore it has adopted propaganda strategies such as publishing white papers like theWhite Paper on Human Rights in China, White Paper on History, Development of Xinjiang, White Paper on Freedom of Religious Belief in China which are aimed at Cinforming and educating the cadres, masses as well as providing justification to the international community on the human rights condition.

This study has also revealed that the CCP has used similar strategies to counter criticisms from Uyghur diaspora groups on the human rights conditions in Xinjiang. The CCP bluntly refused their claims and regard them as terrorists. Therefore the Chinese government has also published several white papers on the conditions in Xinjiang. Another finding highlighted in this study was that, by the mid-1990s, China not only used its economic growth to legitimize its human rights policies, but also as a tool to counter foreign critics. They were aimed to Cprove that despite its non- conformity to the 'western interpretation' of human rights, the - people living in China had been enjoying development and modernisation.

an

- The findings of this study suggest that the liberalisation of policies in Xinjiang in the 1980s was to gain the support of the Uyghurs in order to develop China's agriculture, industry, science and technology and defence. The ultimate aim of the liberalisation was to serve China's national interest by providing some basic freedoms to the Uyghurs so as to seek their cooperation in developing the economy of Xinjiang. The CCP was aware that the Han Chinese would not be able to achieve it without support from the Uyghurs.

The 1990s also witnessedan increase in the migration of Hans into Xinjiang due to the economic boom. It is interesting to point out that from 1990 to 2000 the Han population grew by 31.6 per cent, which was almost twice the growth rate of the Uyghur population (Mahesh Ranjan Debata, 2007). The policy of population transfer to the socio-economic development in Xinjiang became a major source of anger among the Uyghurs who considered the Han immigrantsto have marginalised them and turned them into second-class citizens in their own land. China has attributed the economic success in Xinjiang due to the CCP's firm policies at the expense of sacrificing human rights. 
CCP leaders continue to uphold the idea that the right to economic development supersedes the importance of human rights. They believe that socio-economic development is the way to improve the conditions of China's minorities. The CCP leaders in Xinjiang such as Wang Enmao and Wang Lequan were also convinced that the stability and prosperity of the province were extremely important. Whereas, ensuring that human rights norms were observed was secondary. In fact, if the interest of the CCP in Xinjiang was threatened by separatists they were willing to violate human rights norms.

\section{End Notes}

Khanateis originally a Mongolian word used to describe a political entity ruled by a Khan (Mongolian word for leader or ruler) .This political entity is common for people from Central Asia and it can be equivalent to tribalchiefdom, principality, kingdom or even empire.

2 The People's Liberation Army (PLA) is the unified military organization of all land, sea, strategic missile and air forces of the People's Republic of China. It was founded on 1 August 1927.

It refers to a period between 1956 to 1957 , in PRC, where the CCP encouraged a variety of views and solutions to national policy issues, launched under the slogan: "Letting a hundred flowers blossom and a hundred schools of thought contend is the policy for promoting progress in the arts and the sciences and a flourishing socialist culture in our land." It is also known as Hundred Flowers Movement. The result of the Hundred Flowers Campaign was the persecution of intellectu `als, officials, students, artists and dissidents labeled "rightists" during the AntiRightist Movement that followed. Another important issue of the campaign was the surfaced tensions between the political center and national minorities. Criticism allowed, some of the minorities activists vented their protest against "Han chauvinism" which they saw in formal approach of the party officials toward the local specifics.

Great Leap Forward refers to the economic and social plan used by the PRC during 1958 to 1961. It was initiated by Mao Zedong with the aim to transform China from an agrarian economy into a modern communist society through the process of agriculturalisation, industrialization, and collectivization.The Great Leap ended in catastrophe, triggering a widespread famine_that resulted in up to thirty million deaths. Please refer, Ralph A. Thaxton. Jr., Catastrophe and Contention in Rural China: Mao's Great Leap Forward Famine and the Origins of Righteous Resistance in Da Fo Village, (Cambridge: Cambridge University Press, 2008).

5 Following the 1960s and 1970s Sino-Soviet rivalry and border clashes, China agreed to support the Mujahideens .

6 A situation in which a desired outcome or solution is impossible to attain because of a set of inherently illogical rules or conditions. 
7 SOTA is the acronym for the Ducth abbreviation of 'Foundation for Research into Turkestan, Azerbaijan, Crimea, Caucasus and Siberia'.

8 Amy Reger is a Researcher at the Uyghur Human Rights Project.

\section{References}

Ahmed Rashid. (2002). The resurgence of Central Asia. London: Penguin.

Ahmad Lutfi. (2001). Blowback: China and the Afghan Arabs. Issues \& Studies, 37(1), 180. -

Amnesty International, Library China: Women's rights action 2000 arbitrary detention of Rebiya Kadeer a women's human rights defender and prisoner of conscience. (2000). Retrieved from http://web.amnesty.org

Amnesty International. (1999). Open Letter from Amnesty International to EU Government on the Eve of EU-China Human Rights Dialogue.

Beijing Review. (13-19 February 1994).

China's 'War on Terrorism'-Brutal repression of ethnic unrest in Xinjiang. (2010). Retrieved from http://www.wsws.org/articles/2002/aug2002/chin-a08.shtml

China's changing strategic concerns: The impact on human rights in Xinjiang. (2005). Washington DC: Roundtable before the Congressional-Executive Commission on

China.

Clarke, M. (2009). China, Xinjiang and Central Asia: History, transition and crossborder - interaction into the 21st century, London: Routledge.

Constitution of the People's Republic of China. (1982). Fith national congress of the People's Republic of China. Beijing.

Dillon, M. (2009). Contemporary China an introduction. New York: Routledge.

Dreyer, J. T. (1976). China's political system: Modernization and tradition. London: MacMillan Press.

Dreyer, J. T. (1976). China's forty millions: Minority nationalities and national integration in the People's Republic of China. Cambridge, MA: Harvard University Press.

Forbes A. (1996). The Muslim national minorities of China. Religion, 6, 69. 
Gladney, D. C. (2004). Dislocating China. Chicago: Chicago University Press.

Human Rights in Xinjiang: Recent developments. (2009). Roundtable before the Congressional-Executive Commission on China. Washington DC.

Kent, A. (1993). Between freedom and subsistence China and human rights. Hong Kong: Oxford University Press.

Kostreewa, T. K. (April 1996). Separatist nationalism in Xinjiang (Unpublished Doctoral Thesis). Department of Government Studies, Notre Dame, Indiana.

- Mahesh Ranjan Debata. (2007). China's minorities ethnic-Religious separatism in Xinjiang, New Delhi: Pentagon Press.

Majie, Zhu. (2002). Deng Xiaoping's human rights theory. In Yu Xintian (Ed.), Cultural Impact on International Relations, Cultural heritage and contemporary change series III, Asia, 20, 79-89. The Council for Research in Values and Philosphy. Washington DC.

McMillen, D. (1979). Chinese communist power and policy in Xinjiang. Boulder, CO: Westview Press.

Millward, J. A. (2005). Eurasian Crossroads a History of Xinjiang. New York: Columbia University Press.

Nathan, A. J. (1994). Human rights in Chinese foreign policy. The China Quarterly, 139, 641.

Rogers, R.A. (2007). The Shanghai cooperation organisation China and the new great game in Central Asia. Journal of International Studies, 3, 93.

Shichor, Yitzhak. (2002). Virtual Transnationalism: Uyghur communities in Europe and the quest for Eastern Turkistan Independence. (Unpublished paper).

Special Report about the human rights situation in Eastern Turkistan for the period of January-May 2002. (2010,February 19). Retrieved form http://uyghur.org

UAA urges PRC to adhere to International Legal Norms. Retrieved from http://www. uyghuramerican.org//articles/1569/1/UAA.

Хinhua.(2, March 1994; 21 January,1 February, 6 February, 2002).

Xinjiang Statistical Yearbook. (2005). Beijing: Beijing Information Press. 
Yusuf,Liu Baojn.(1998). A glance of China Muslims. Kuala Lumpur: Malaysia Encyclopedia Research Center Berhad.

War on Terror or Misguided Muscle?. (n.d.). Retrieved from http://www.stanleyfoundation. org

Wei, Cuiyi. (1993). An historical survey of modern Uighur writing since the 1950s in Xinjiang, China. Central Asia Journal, 37(4), 270.

Wei, Zhou. (1995). There study of human rights in the people's Republic of China in Human Rights and International Relations in the Asia Pacific Region, edited by James T.H. Tang, New York: Pinter. 